\title{
The Associations of Androgen-Related Genes CYP2IA2 and CYPI9AI with Severe Acne Vulgaris in Patients from Southwest China
}

This article was published in the following Dove Press journal: Clinical, Cosmetic and Investigational Dermatology

\author{
Ting Yang ${ }^{1,2}$ \\ Wen-Juan $\mathrm{Wu}^{\prime}$ \\ Li-Ming $\operatorname{Tian}^{3}$ \\ Deng-Feng Zhang ${ }^{4}$ \\ Xiao-Yan Yang' \\ Jue $Q i^{1}$ \\ Ying Tu' \\ $\mathrm{Li} \mathrm{He}$
}

'Department of Dermatology, First Affiliated Hospital of Kunming Medical University, Kunming, Yunnan, 650023,

People's Republic of China; ${ }^{2}$ Department of Dermatology, Huangshi Central Hospital, Affiliated Hospital of Hubei Polytechnic University, Edong Healthcare Group, Huangshi, Hubei, 435000, People's Republic of China; ${ }^{3}$ Department of Dermatology, First Hospital of Wuhan, Tongii Medical College, Huazhong University of Science and Technology, Wuhan, Hubei, 430022, People's Republic of China; ${ }^{4}$ Key Laboratory of Animal Models and Human Disease Mechanisms of the Chinese Academy of Sciences and Yunnan Province, Kunming Institute of Zoology, Kunming, Yunnan, 650223, People's Republic of China
Correspondence: $\mathrm{Li} \mathrm{He}$ Department of Dermatology, First Affiliated Hospital of Kunming Medical University, No. 295 Xichang Road, Wuhua District, Kunming, Yunnan, 650023,

People's Republic of China

$\mathrm{Tel} / \mathrm{Fax}+86$ 087I-65317895

Email lihe_4785@I63.com
Objective: Androgens acting through the androgen receptor play a crucial role in the pathogenesis of acne. This study aimed to identify whether two key genes (CYP21A2 and CYP19A1) involved in the synthesis and metabolism of androgens were associated with Pillsbury III-IV severe acne vulgaris.

Methods: We carried out a standard questionnaire survey about acne and enlisted 600 Pillsbury III-IV severe acne vulgaris patients and 652 healthy controls of Han Chinese descent from Yunnan, China in the study. Twenty-two single nucleotide polymorphisms (SNPs) were genotyped by SNaPshot assay and analyzed for association with severe acne. Results: There was no significant difference in gender between the two groups $(P=0.085)$, and the age of the acne case group was significantly lower than that of the control group $(P<$ $0.001)$. Our results revealed that only two SNPs, rs6474 (p.Arg102Lys) $(P=0.001)$ and rs6465 $(P=0.025)$ of the $C Y P 21 A 2$ gene were significantly associated with severe acne among the Han Chinese. When subjects were divided into males and females, significant associations were observed only in male patients with severe acne vulgaris for four variants: CYP21A2 rs6474 (p.Arg102Lys) $(P=0.002) ; C Y P 21 A 2$ rs6465 $(P=0.012) ; C Y P 19 A 1$ rs8023263 $(P=0.037)$; and $C Y P 19 A 1$ rs2470152 $(P=0.007)$. Haplotype analyses showed that the distribution of $C Y P 21 A 2$ haplotypes was significantly associated with male patients, while no association of $C Y P 19 A 1$ haplotypes was observed. The structure of the human CYP21A2 consists of two substrate binding sites and one substrate access channel.

Conclusion: This study shed a light on a potentially important effect of CYP21A2 and CYP19A1 genes in severe acne vulgaris in the Han Chinese, especially for male patients. Future studies using independently verified datasets from a broader geographical spectrum will be valuable in identifying the causal and functional variants responsible for severe acne vulgaris within the CYP19A1 and CYP21A2 genes.

Keywords: androgen receptor, severe acne, synthesis, metabolism, genetic risk

\section{Introduction}

Acne is estimated to affect $9.4 \%$ of the global population, making it the eighth most prevalent disease worldwide. ${ }^{1}$ Acne can be a painful and disfiguring disease, which leaves some individuals with permanent physical and psychological scars.,3 Likewise among those suffering from severe acne, suicidal ideation is markedly more common, ${ }^{4}$ highlighting the severe psychological toll that this disease can take. Thus, severe acne can be considered a public health problem. Several factors have been implicated in the development of acne, including androgen, sebum overproduction, abnormal follicular infundibular function, proliferation of Cutibacterium 
acnes, and inflammation, as well as lifestyle and heredity. ${ }^{3,5}$ In particular, Cutibacterium acnes play an important role in promoting the inflammatory responses by enhancing the secretion of cytokines, such as tumor necrosis factor (TNF)- $\alpha$, interleukin (IL)- 8 and IL-12 from the phagocytes and keratinocytes. ${ }^{6}$ The heritability of the disease suggests a probable genetic mechanism.

Androgens, which enhance sebum production and follicular keratosis, play an essential role in the development of acne. ${ }^{7}$ However, the exact genetic mechanisms underlying how androgens affect acne development remain unclear. Certain androgen-related genes were found to be the risk factors of acne, especially for severe acne, although support for these associations has not been unanimous. Previous studies have focused on genes, such as CYP $1 A 1,{ }^{8}$ $C Y P 17,{ }^{5}$ and androgen receptors $(A R s) .{ }^{9}$ Consequently, in this study, we opted to focus on examining whether CYP21A2 and CYP19A1 are associated with acne vulgaris.

$C Y P 21 A 2$ is localized on the chromosome $6 \mathrm{p} 21.3$ in the region of the major histocompatibility complex of class III. An earlier study of $C Y P 21 A 2$ polymorphism among random acne patients found that alterations of the CYP21A2 gene were more common in patients with acne than in the controls, but there is a poor correlation between these changes and increased steroids and acne. ${ }^{10}$ To date, there are no other associational studies that explore the relationship between $C Y P 21 A 2$ and acne.

CYP19A1 is located on the long arm of chromosome 15 at position $15 \mathrm{q} 21.1$, and it encodes aromatase, a key steroidogenic enzyme that catalyzes the final step of estrogen biosynthesis through the aromatization of testosterone and androstenedione. ${ }^{11}$ Polymorphisms of the CYP19A1 gene encoding aromatase have been reported to be correlated with plasma testosterone levels, and some studies proposed that the polymorphisms of the CYP19A1 gene had a positive association with some androgen-related diseases, such as hyperandrogenism, PCOS, ${ }^{12,13}$ prostate cancer, ${ }^{14}$ female pattern hair loss, ${ }^{15}$ and some estrogen dependent diseases such as breast cancer, ${ }^{16,17}$ endometrial cancer, ${ }^{18}$ and endometriosis, ${ }^{19,20}$ and changes in the timing of the menarche. ${ }^{21,22}$

Taking into account these reports on the potential effects of both $C Y P 21 A 2$ and $C Y P 19 A 1$, we hypothesized that CYP21A2 and CYP19A1, being two key genes involved in the synthesis and metabolism of androgens, may be related to the occurrence of acne, in particular of severe acne vulgaris, and we performed a systematic genetic analysis, with a relatively large sample size of Han Chinese, based on a case-control study.

\section{Materials and Methods Subject Selection and Information Gathering Protocols}

A total of 1252 unrelated Han Chinese individuals, 600 patients and 652 controls, were recruited from Yunnan, in the southwest of China, for this study. All the patients were examined in succession in the outpatient unit of dermatology at the first affiliated hospital of Kunming Medical University, by dermatologists using the Pillsbury Classification Scale. ${ }^{23}$ Patients who present with Pillsbury III-IV according to the criteria were recruited. Severe acne lesions were characterized predominantly as inflammatory papules, pustules, nodules, scars and cysts. ${ }^{24}$ In this study, we enrolled those patients who presented with inflammatory nodules, scars and cysts, or accompanied with large pus-filled cysts, substantial swelling and exfoliation around the infections, in addition to comedones, papules and pustules. We then collected 652 gender-matched healthy people as controls. The subjects were then divided into a male and a female group. Written informed consent was obtained from all subjects, and this study was approved by the ethics board of Kunming Medical University. This study was conducted in accordance with the Declaration of Helsinki.

\section{Content of Questionnaire}

The subjects recruited for the case group were given a standardized questionnaire concerning their personal information (age, gender, ethnicity, occupation, place of birth and family residence, weight, and height), socioeconomic situation (religion, dietary habits, smoking and alcohol, skin type, genetic factors, drug history, and past medical history), acne status (age at onset, duration, location and type of skin lesions, season at onset, and aggravated season), risk factors (menstrual cycle, sun exposure, emotional impact, and agrypnia), familial hereditary history, and hobbies. The data were collected from 539 (89.8\%) cases using these questionnaires.

\section{Standard for Exclusion}

The exclusion criteria were as follows: those with 1) endocrine diseases, such as polycystic ovary syndrome, diabetes, hyperthyroidism, CAH or thyropenia; 2) other genetic diseases; 3) androgen-related diseases; 4) serious digestive diseases; 5) infectious diseases; 6) occupational 
Table I The Basic Characteristics of All SNPs for the CYP2 IA2 and CYPI9AI Genes

\begin{tabular}{|c|c|c|c|c|c|}
\hline Number & SNP ID & Position (bp) ${ }^{a}$ & Allele & MAF $^{b}$ & Location/Annotation \\
\hline \multicolumn{6}{|l|}{ CYP2IA2 } \\
\hline I & rs6464 & 32114316 & $\mathrm{~A} / \mathrm{C}$ & 0.158 & Exon I/tag SNP \\
\hline 2 & rs6467 & 32114837 & $\mathrm{~T} / \mathrm{G}$ & 0.300 & Intron2/tag SNP \\
\hline 3 & rs6474 & 32114865 & $\mathrm{G} / \mathrm{A}$ & 0.222 & Exon3/tag SNP \\
\hline 4 & rs6465 & 32115740 & $\mathrm{C} / \mathrm{T}$ & 0.162 & Intron6/tag SNP \\
\hline \multicolumn{6}{|l|}{ CYPI9AI } \\
\hline I & rs4646 & 49290136 & $\mathrm{C} / \mathrm{A}$ & 0.280 & 3-UTR \\
\hline 2 & rs 10046 & 49290278 & $\mathrm{~T} / \mathrm{C}$ & 0.439 & 3-UTR \\
\hline 3 & rs700519 & 49295260 & $\mathrm{C} / \mathrm{T}$ & 0.146 & Exon7 \\
\hline 4 & rs8023263 & 49304889 & $\mathrm{G} / \mathrm{T}$ & 0.415 & Intron4/tag SNP \\
\hline 5 & rs2899473 & 49306365 & $\mathrm{C} / \mathrm{T}$ & 0.146 & Intron4/tag SNP \\
\hline 6 & rs 12594287 & 49311199 & $\mathrm{G} / \mathrm{A}$ & 0.232 & Intron3/tag SNP \\
\hline 7 & rs24I4096 & $493|707|$ & $\mathrm{G} / \mathrm{A}$ & 0.425 & Intron2 \\
\hline 8 & rs727479 & 49321839 & $\mathrm{~T} / \mathrm{G}$ & 0.237 & Intron2/tag SNP \\
\hline 9 & rs767199 & 49327679 & $\mathrm{G} / \mathrm{A}$ & 0.488 & Intron I/tag SNP \\
\hline 10 & rsII636667 & 49329485 & $\mathrm{C} / \mathrm{T}$ & 0.488 & Intron I/tag SNP \\
\hline II & rs749292 & 49346023 & $\mathrm{G} / \mathrm{A}$ & 0.476 & Intron I/tag SNP \\
\hline 12 & rs730I54 & 49378496 & $A / G$ & 0.305 & Exon 1.4/tag SNP \\
\hline 13 & rs28757III & 49380750 & $\mathrm{~T} / \mathrm{C}$ & 0.159 & Intron I/tag SNP \\
\hline 14 & rs2470I52 & 49382264 & $\mathrm{~T} / \mathrm{C}$ & 0.500 & Intron I/tag SNP \\
\hline 15 & rs4I399553 & 49383121 & $\mathrm{C} / \mathrm{T}$ & 0.134 & Intron I/tag SNP \\
\hline 16 & rsI902584 & 49398946 & $\mathrm{~A} / \mathrm{T}$ & 0.122 & Intron I/tag SNP \\
\hline 17 & rs1004984 & 49400821 & $\mathrm{C} / \mathrm{T}$ & 0.295 & Intron I/tag SNP \\
\hline 18 & rs $28757078^{c}$ & 49412515 & $\mathrm{C} / \mathrm{T}$ & 0.207 & Intron I/tag SNP \\
\hline
\end{tabular}

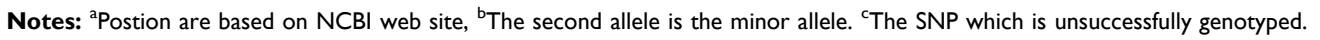

acne or pharmacological acne tetter; and those who had 7) had acne for less than six months; 8) taken tretinoin or other hormones within two months prior to possible enrollment. $^{3}$

\section{SNP Selection and Genotyping}

Genomic DNA was extracted from the whole blood of all patients and controls using the AxyPrep ${ }^{\mathrm{TM}}$ Blood Genomic DNA Miniprep Kit (Axygen, USA), following the procedure detailed in the kit. The DNA samples were stored at $-20^{\circ} \mathrm{C}$. The information of 18 CYP19A1 and 4 CYP21A2 single nucleotide polymorphisms (SNPs) was acquired from public databases NCBI dbSNP, (http://www.ncbi.nlm.nih.gov/projects/SNP/); and HapMap, (http://hapmap.ncbi.nlm.nih.gov/, Phase $3, \mathrm{CHB}$ ), under a rationale of minor allele frequency (MAF) $>10 \%$. Among the 22 SNPs, 18 (CYP19A1:14 SNPs; CYP21A2:4 SNPs) were marked as tag SNPs in the HapMap dataset for CHB. Another 4 SNPs of the CYP19A1 gene, rs4646 and rs10046 (in the 3'-UTR), rs700519 (Arg264Cys), and rs2414096, have been extensively studied in hyperandrogenism diseases. The basic characteristics of the selected SNPs for the CYP21A2 and CYP19A1 genes are presented in Table 1.

All the SNPs were genotyped using SNaPshot assay, for multiplex polymerase chain reactions (PCRs). PCR primers and extension primers for all 21 successfully genotyped SNPs are presented in Table 2 (rs28757078 of CYP19A1 was abandoned because of insufficient power to detect its effects). GeneMarker (Holland and Parson, 2011) was used to read the genotyping results. For quality control, a 4\% masked random sample of cases and controls was tested repetitively by direct sequencing, and all the results were $100 \%$ concordant.

\section{Functional Implications of the SNP rs6474 (p.Arg102Lys) from Structure Modeling}

In order to infer the functional implications of the SNP rs6474 (p.Arg102Lys) the structure of human CYP21A2 
Table 2 Primers for All Genotyped SNPs of the CYP2 IA2 and CYPI9AI Genes

\begin{tabular}{|c|c|c|c|}
\hline Num. & SNP ID & \multicolumn{2}{|c|}{ Primer $\left(5^{\prime}-3^{\prime}\right)$} \\
\hline \multicolumn{4}{|l|}{ CYP2 IA2 } \\
\hline 1 & rs6464 & $\begin{array}{l}\text { Forward } \\
\text { Reverse } \\
\text { Extension }\end{array}$ & $\begin{array}{l}\text { CTGCTGTGGAACTGGTGGAAG } \\
\text { TGTAGATGGGCCCGAATTTCTG } \\
\text { TTTTTTTTTTTTTTTTTTTTAGTCAGGCCAAGCAGATAGAT }\end{array}$ \\
\hline 2 & rs6467 & $\begin{array}{l}\text { Forward } \\
\text { Reverse } \\
\text { Extension }\end{array}$ & $\begin{array}{l}\text { CTCAGCTGCCTTCATCAGTTC } \\
\text { GTGAGCTTCTTGTGGGCTTTC } \\
\text { TTTTTTTTTTTTTTTTTCCAGCTTGTCTGCAGGAGGAG }\end{array}$ \\
\hline 3 & rs6474 & $\begin{array}{l}\text { Forward } \\
\text { Reverse } \\
\text { Extension }\end{array}$ & $\begin{array}{l}\text { CTCAGCTGCCTTCATCAGTTC } \\
\text { GTGAGCTTCTTGTGGGCTTTC } \\
\text { TTTTTAAGGACAGGTCCGGGTAGTTC }\end{array}$ \\
\hline 4 & rs6465 & $\begin{array}{l}\text { Forward } \\
\text { Reverse } \\
\text { Extension }\end{array}$ & $\begin{array}{l}\text { TTTGCATACCCCAGTTATGGGC } \\
\text { ATGTAGTCCATCATGTCCCTC } \\
\text { TTTTCCTGCAGAGGGTGAAAGGAGC }\end{array}$ \\
\hline \multicolumn{4}{|l|}{ CYPI9AI } \\
\hline 1 & rs4646 & $\begin{array}{l}\text { Forward } \\
\text { Reverse } \\
\text { Extension }\end{array}$ & $\begin{array}{l}\text { GCTGGAAATGATCTTTACCCC } \\
\text { TTCACCGACTATTTCTCCCTC } \\
\text { TTTTTTTTTTTTTTTGTGTGAACAGGAGCAGATGAC }\end{array}$ \\
\hline 2 & rs 10046 & $\begin{array}{l}\text { Forward } \\
\text { Reverse } \\
\text { Extension }\end{array}$ & $\begin{array}{l}\text { GCTGGAAATGATCTTTACCCC } \\
\text { TTCACCGACTATTTCTCCCTC } \\
\text { TTTTTTTTTTTGATGAGAAATGCTCCAGAGT }\end{array}$ \\
\hline 3 & rs700519 & $\begin{array}{l}\text { Forward } \\
\text { Reverse } \\
\text { Extension }\end{array}$ & $\begin{array}{l}\text { CAGCAAGGATTTGAAAGATGCC } \\
\text { TAGTTCAGGTCAGTACCTCTG } \\
\text { TTTTTTTTTTTTTTTTCTCTTCTGTGGAAATCCTGC }\end{array}$ \\
\hline 4 & rs8023263 & $\begin{array}{l}\text { Forward } \\
\text { Reverse } \\
\text { Extension }\end{array}$ & $\begin{array}{l}\text { СCTAATACACCTGAGCCAAATG } \\
\text { TTCCСCTATCCACAAAAGGTG } \\
\text { TTTTTTTTTTTTTTTTTTTTTTGAAATAATGCTATAAGATCC }\end{array}$ \\
\hline 5 & rs2899473 & $\begin{array}{l}\text { Forward } \\
\text { Reverse } \\
\text { Extension }\end{array}$ & $\begin{array}{l}\text { CTGGATAAGGAAGCTTGCAAC } \\
\text { CCATATCTGTCATCTAGCCTC } \\
\text { TTTTTTGAGGAAATAAAGTTCCAAC }\end{array}$ \\
\hline 6 & rs 12594287 & $\begin{array}{l}\text { Forward } \\
\text { Reverse } \\
\text { Extension }\end{array}$ & $\begin{array}{l}\text { CTCGGTTAAATTCAAGTGGGC } \\
\text { GGAAATAAAGTCTTCAGCTGGG } \\
\text { TTTTTTTTTTTGACATGCAGTAGCATTGCCAG }\end{array}$ \\
\hline 7 & rs24I4096 & $\begin{array}{l}\text { Forward } \\
\text { Reverse } \\
\text { Extension }\end{array}$ & $\begin{array}{l}\text { GGAGAATGTCCAATCCAAGAAC } \\
\text { TTCAAAGACCCATTGCCTGAC } \\
\text { TTTTTTTTTTTTTTTTTGCTTAAGAGCCTTTTCTTAAA }\end{array}$ \\
\hline 8 & rs727479 & $\begin{array}{l}\text { Forward } \\
\text { Reverse } \\
\text { Extension }\end{array}$ & $\begin{array}{l}\text { CTGGAACATCTTCTTCACTGC } \\
\text { CACTATCACCACATTCCCAAG } \\
\text { TTTTTTTTTTTTTTTTTTTTTTTTCAAGACAAAGAGGGGGCATGG }\end{array}$ \\
\hline 9 & rs767199 & $\begin{array}{l}\text { Forward } \\
\text { Reverse } \\
\text { Extension }\end{array}$ & $\begin{array}{l}\text { CCAAGCTCTAGTGTCTTCAAG } \\
\text { TGGAGAGATGGTTTGTTTGGC } \\
\text { TTTTTGTGCTGCAGTCCATTCCCCAC }\end{array}$ \\
\hline
\end{tabular}

(Continued) 
Table 2 (Continued).

\begin{tabular}{|c|c|c|c|}
\hline Num. & SNP ID & \multicolumn{2}{|c|}{ Primer $\left(5^{\prime}-3^{\prime}\right)$} \\
\hline 10 & rsII636667 & $\begin{array}{l}\text { Forward } \\
\text { Reverse } \\
\text { Extension }\end{array}$ & $\begin{array}{l}\text { TCATGACACTTGAGGTTCCAG } \\
\text { CACACCATGTGTATCTAGCTG } \\
\text { TTTTTTTTTTTTTTTTTGAGCAAGACAATAGGAACCAA }\end{array}$ \\
\hline 11 & rs749292 & $\begin{array}{l}\text { Forward } \\
\text { Reverse } \\
\text { Extension }\end{array}$ & $\begin{array}{l}\text { TATGGAAGGAGGACTGAGTGG } \\
\text { GGCCTGATAGAAATTGTGCAG } \\
\text { TTTTTTTTTTCCTTCTTCAAACCTCGGAGTC }\end{array}$ \\
\hline 12 & rs730154 & $\begin{array}{l}\text { Forward } \\
\text { Reverse } \\
\text { Extension }\end{array}$ & $\begin{array}{l}\text { TTGCCGGTTCCAGCAAAACTTC } \\
\text { CCTGAGCTCATTGCTAATGTG } \\
\text { TTTTTCCAGCAAAACTTCATGGAGC }\end{array}$ \\
\hline 13 & rs28757III & $\begin{array}{l}\text { Forward } \\
\text { Reverse } \\
\text { Extension }\end{array}$ & $\begin{array}{l}\text { CTTGGAAAGGAAGCTTTGTGC } \\
\text { TACTGGACTTGGCTATGTTGC } \\
\text { TTTTTTTTTTTTTTTTTAAAACAAAGAATCTCAGGGTA }\end{array}$ \\
\hline 14 & rs2470I52 & $\begin{array}{l}\text { Forward } \\
\text { Reverse } \\
\text { Extension }\end{array}$ & $\begin{array}{l}\text { CAATTTCAAGGGTTGTGGGAC } \\
\text { AATCTCTGCCTGTGGAAAGTC } \\
\text { TTTTTTTTTTTTTTTTTTTTCTTCTTTGATGTCCAGCCCAC }\end{array}$ \\
\hline 15 & rs41399553 & $\begin{array}{l}\text { Forward } \\
\text { Reverse } \\
\text { Extension }\end{array}$ & $\begin{array}{l}\text { TTGAGGCATCTGCCTTCTTAG } \\
\text { CTACTTATCTGCCCCTTAGAG } \\
\text { TTTTTTTTTTTTCCTTGTATTTGCTCAGACA }\end{array}$ \\
\hline 16 & rs 1902584 & $\begin{array}{l}\text { Forward } \\
\text { Reverse } \\
\text { Extension }\end{array}$ & $\begin{array}{l}\text { TCCTGTTAGATACAGATGCAC } \\
\text { GGTGATGGGTTATGAGGATTAG } \\
\text { TTTTTTTTTTTTTTTTTTTTTTTTTCACATACAATTCTTATGAACA }\end{array}$ \\
\hline 17 & rs 1004984 & $\begin{array}{l}\text { Forward } \\
\text { Reverse } \\
\text { Extension }\end{array}$ & $\begin{array}{l}\text { AAATTGGATTGTGGCAGAGGG } \\
\text { AАTCATCACTGATGGACCCTG } \\
\text { TTTTTTTTTTTTTTTCССССАTGACTGССТАСTGTT }\end{array}$ \\
\hline
\end{tabular}

was modeled by using the bovine $C Y P 21 A 2$ structure as a template. The bovine CYP21A2 crystal structure (PDB: 3QZ1) complexed with the substrate 17-OHP was obtained from the Protein Data Bank. Discovery Studio 3.1 (Accerlrys, San Diego, CA) was used to perform homology modeling.

\section{Statistical Analysis}

All statistical analyses were performed using SPSS v.17.0 (IBM Corp., Armonk, NY, USA). The Hardy-Weinberg equilibrium (HWE) test was carried out for each SNP in the control group using Chi-square tests. Genotype frequency differences in each SNP between Pillsbury III-IV severe acne vulgaris patients and the corresponding control subjects were estimated by the unconditional logistic regression model, adjusted for age. The pairwise linkage disequilibrium (LD) between the CYP19A1 gene and the CYP21A2 gene in the control group was performed using Haploview software version 4.2. ${ }^{25}$ Haplotype block structures were defined as previously described, ${ }^{26}$ and haplotype frequency was estimated using PHASE 2.0. The global difference in haplotype frequencies between the cases and controls was estimated using Chi-square tests. Haplotype frequencies of the two candidate genes were further subject to Bonferroni correction to account for multiple comparisons. The conservative significance threshold for a single test was assessed at a type I error rate of $0.05 / \mathrm{N}$, where $\mathrm{N}$ was the number of tested markers for each haplotype.

\section{Results}

\section{Clinical Features}

Overall, both groups were similar with respect to gender, while the mean age of the control group was higher than that of the acne case group, so as to mitigate the possibility that some of the younger controls might develop acne later on. The clinical characteristics of patients with severe acne 
vulgaris are summarized in Table 3. In general, age of acne onset, skin type, and severity of acne symptoms were significantly different between males and females; the frequency of cysts or nodules, hypertrophic scarring and atrophic scarring is higher in male patients. In other words, the clinical symptoms of acne were more severe among male patients. Risk factors among the males were males included smoking, alcohol consumption, and a diet heavy in lard and oil. Females were more affected by anxiety and depression and suffered from poor quality of sleep. Additionally, 56.8\% of acne in female acne patients was reported to be related to their menstrual cycles. A large portion of both male patients (75.3\%) and female patients $(62.7 \%)$ had a family history of acne dating back within one generation.

\section{Basic Characteristics}

A total of 569 patients $(94.8 \%, 22.62 \pm 6.30$ years old; 348 males and 221 females) and 631 controls (96.8\%, $26.76 \pm$ 8.05 years old; 355 males and 276 females) were successfully genotyped and included for further analysis in the present study. Age and gender characteristics of both the case and control groups are shown in Table 4.

CYP2 IA2 rs6474 (p.Arg 102Lys) and rs6465 are Associated with Pillsbury III-IV Severe Acne Vulgaris

The linkage disequilibrium map of the tested SNPs among the control populations is shown in Figure 1. The genotypes of selected polymorphisms of CYP19A1 and CYP21A2 followed the Hardy-Weinberg equilibrium, with significant values $(P<0.01)$ except for rs6465 in the control group $(P=0.0006)$, which was accordingly excluded for further analysis. Two $C Y P 21 A 2$ SNPs and two CYP19A1 SNPs showed significant associations with severe acne vulgaris (Table 5). The other 17 SNPs showed no significant association in male- or female-severe acne (Table 6). Genotype AA of rs6474 (p.Arg102Lys) of the CYP21A2 gene had a significantly higher frequency in severe acne vulgaris patients $(\mathrm{OR}=5.431,95 \% \mathrm{CI}$ : 2.060-14.318, $P=0.001)$. By contrast, the genotype TT of rs6465 (intron 6) of the CYP21A2 gene had a significantly lower frequency in severe acne vulgaris patients $(\mathrm{OR}=0.417,95 \% \mathrm{CI}: 0.194-0.896, P=$ 0.025). However, there was no apparent association with severe acne vulgaris in the four reported SNPs of CYP19A1 gene, rs4646 and rs10046 (in the 3'-UTR), rs700519 (Arg264Cys), rs2414096, which have been extensively studied in hyperandrogenism diseases (Table 6).

\section{Associations of CYP2 IA2 and CYPI9AI with Severe Acne Vulgaris Among Males}

Our previous studies suggested that the existence of shorter $A R$ gene CAG repeat polymorphism and the CYP17 $-34 \mathrm{C} / \mathrm{T}$ homozygote in males results in a significantly increased risk of developing severe acne. As such, we grouped the subjects into males and females with severe acne vulgaris and paired them with their corresponding controls. There were significant differences between male patients and controls for the genotype AA of rs6474 (p.Arg102Lys) and the genotype TT of rs6465 of CYP21A2, as well as the genotype GT of rs8023263 and the genotype CT of rs 2470152 of the CYP19A1 gene (rs6474, OR $=11.7 P=0.002 ;$ rs6465, OR $=0.272, P=0.012 ;$ rs8023263, OR $=0.658, P=0.037$; rs2470152, $\mathrm{OR}=1.675, P=0.007)$. Similarly, the allele A of rs6474 (p.Arg102Lys) and the allele T of rs6465 in the CYP21A2 gene showed significant differences in the incidence of severe acne vulgaris between male subjects and controls (rs6467 A allele, $\mathrm{OR}=1.542, P=0.006 ;$ rs6465 T allele, $\mathrm{OR}=0.717, P=0.039$ ). The allele frequencies of both SNPs rs8023263 and rs2470152 of CYP19A1 were similar between the males with severe acne vulgaris and the male controls (Table 5).

\section{Lack of Association of CYP2 IA2 and CYPI 9A I with Severe Acne Vulgaris in Females}

There was no evidence of association of the 21 SNPs with risk for female severe acne vulgaris $(P>0.05)$ for both CYP21A2 and CYP19A1 at either the genotype or the allele level. The data of the above mentioned 4 SNPs are shown in Table 5, and the data of the other 17 SNPs are shown in Table 6.

\section{Haplotype Analysis of CYP2 IA2 and CYPI9AI}

The linkage disequilibrium plot of the two candidate genes is presented in Figure 1. We reconstructed haplotypes of the 3 SNPs of the CYP21A2 gene. For the CYP19A1 gene, a total of 17 variants were considered and divided into three haplotype blocks, with the aggregate data from the control group. Also presented in Table 7 are the association results of risk of severe acne with common haplotypes in each haplotype block. The analyses include all subjects, as well as analyses conducted in the male or female population. We pooled together those haplotypes with a frequency of $<3 \%$ in the case or control groups and compared distribution 
Table 3 The Clinical Characteristics of Severe Acne in Male and Female Patients

\begin{tabular}{|c|c|c|c|c|}
\hline \multirow[t]{2}{*}{ Characteristics } & \multicolumn{2}{|c|}{ Number of Patients* } & \multirow[t]{2}{*}{$\chi^{2}$} & \multirow[t]{2}{*}{$P$} \\
\hline & Male (325) & Female $(2 \mid 4)$ & & \\
\hline Age (years) & $21.3 \pm 5.45$ & $24.5 \pm 6.79$ & & \\
\hline \multicolumn{5}{|l|}{ Age of onset (years) } \\
\hline $10-15$ & $15 \mid(46.6 \%)$ & 87 (40.8\%) & 11.957 & 0.018 \\
\hline $16-20$ & $137(42.3 \%)$ & 91 (42.7\%) & & \\
\hline $21-25$ & 27 (8.3\%) & 15 (7.0\%) & & \\
\hline $26-30$ & $3(0.9 \%)$ & $9(4.2 \%)$ & & \\
\hline$>30$ & $6(1.9 \%)$ & II (5.2\%) & & \\
\hline \multicolumn{5}{|l|}{ Skin types } \\
\hline Oil type & 296 (91.1\%) & $173(80.8 \%)$ & 15.223 & $<0.001$ \\
\hline Dry type & $13(4.0 \%)$ & $10(4.7 \%)$ & & \\
\hline Mixed type & $16(4.9 \%)$ & 31 (I4.5\%) & & \\
\hline \multicolumn{5}{|l|}{ Type of skin lesions } \\
\hline \multicolumn{5}{|l|}{ Comedones (n) } \\
\hline 0 & $13(4.0 \%)$ & $6(2.8 \%)$ & 2.649 & 0.449 \\
\hline $\mathrm{I}-50$ & $238(73.2 \%)$ & 147 (68.7\%) & & \\
\hline $51-100$ & $52(16.0 \%)$ & $44(20.6 \%)$ & & \\
\hline$>100$ & $22(6.8 \%)$ & 17 (7.9\%) & & \\
\hline \multicolumn{5}{|l|}{ Papule (n) } \\
\hline 0 & $3(0.9 \%)$ & $6(2.8 \%)$ & 5.537 & 0.136 \\
\hline $1-50$ & $254(78.2 \%)$ & $15 \mid(70.9 \%)$ & & \\
\hline $59-100$ & 49 (15.1\%) & $38(17.8 \%)$ & & \\
\hline$>100$ & $19(5.8 \%)$ & $18(8.5 \%)$ & & \\
\hline \multicolumn{5}{|l|}{ Cyst or nodules (n) } \\
\hline 0 & $46(14.2 \%)$ & 79 (36.9\%) & 40.134 & $<0.001$ \\
\hline $1-10$ & $195(60.0 \%)$ & 105 (49.1\%) & & \\
\hline$>10$ & $84(25.8 \%)$ & 30 (14.0\%) & & \\
\hline \multicolumn{5}{|l|}{ Hypertrophic scar (n\%) } \\
\hline $0 \%$ & $127(39.2 \%)$ & 148 (69.2\%) & 46.83 & $<0.001$ \\
\hline $\mathrm{I}-25 \%$ & I7I (52.8\%) & $58(27.1 \%)$ & & \\
\hline $25-50 \%$ & $20(6.2 \%)$ & $5(2.3 \%)$ & & \\
\hline$>50 \%$ & $6(1.9 \%)$ & $3(1.4 \%)$ & & \\
\hline \multicolumn{5}{|l|}{ Atrophic scar (n\%) } \\
\hline $0 \%$ & $63(19.4 \%)$ & 85 (39.7\%) & 28.103 & $<0.001$ \\
\hline $\mathrm{I}-25 \%$ & $216(66.7 \%)$ & $111(51.9 \%)$ & & \\
\hline $25-50 \%$ & $29(9.0 \%)$ & 14 (6.5\%) & & \\
\hline$>50 \%$ & $16(4.9 \%)$ & $4(1.9 \%)$ & & \\
\hline \multicolumn{5}{|l|}{ Season at onset } \\
\hline Spring & I 4 (4.4\%) & I4 (6.5\%) & 4.956 & 0.292 \\
\hline Sunmmer & $286(89.1 \%)$ & $185(185)$ & & \\
\hline Fall & $5(1.6 \%)$ & $3(1.4 \%)$ & & \\
\hline Winter & $4(1.2 \%)$ & $0(0.0 \%)$ & & \\
\hline Reversal of season & 12 (3.7\%) & $12(5.6 \%)$ & & \\
\hline
\end{tabular}

(Continued) 
Table 3 (Continued).

\begin{tabular}{|c|c|c|c|c|}
\hline \multirow[t]{2}{*}{ Characteristics } & \multicolumn{2}{|c|}{ Number of Patients* } & \multirow[t]{2}{*}{$\chi^{2}$} & \multirow[t]{2}{*}{$P$} \\
\hline & Male (325) & Female $(2 \mid 4)$ & & \\
\hline $\begin{array}{l}\text { Aggravate season } \\
\text { Spring } \\
\text { Sunmmer } \\
\text { Fall } \\
\text { Winter }\end{array}$ & $\begin{array}{l}101(31.4 \%) \\
200(62.1 \%) \\
3(0.9 \%) \\
18(5.6 \%)\end{array}$ & $\begin{array}{l}75(35.0 \%) \\
125(58.4 \%) \\
0(0.0 \%) \\
14(6.5 \%)\end{array}$ & 3.01 & 0.390 \\
\hline Dietary habits & & & & \\
\hline $\begin{array}{l}\text { Smoking } \\
\text { Never } \\
\text { I-10 cigarette/d } \\
10-20 \text { cigarette/d } \\
>20 \text { cigarette/d }\end{array}$ & $\begin{array}{l}217(71.4 \%) \\
57(18.8 \%) \\
23(7.6 \%) \\
7(2.3 \%)\end{array}$ & $\begin{array}{l}191(90.5 \%) \\
16(7.6 \%) \\
4(1.9 \%) \\
0(0.0)\end{array}$ & 29.213 & $<0.001$ \\
\hline $\begin{array}{l}\text { Alcohol } \\
\text { Never } \\
\text { Once-twice/week } \\
\text { More than third week }\end{array}$ & $\begin{array}{l}257(82.4 \%) \\
42(13.5 \%) \\
13(4.2 \%)\end{array}$ & $\begin{array}{l}192(93.2 \%) \\
13(6.3 \%) \\
1(0.5 \%)\end{array}$ & 13.876 & 0.001 \\
\hline $\begin{array}{l}\text { Eggs } \\
\text { Less than once/week } \\
\text { Once-thrid/week } \\
\text { More than third week }\end{array}$ & $\begin{array}{l}73(22.9 \%) \\
122(38.2 \%) \\
124(38.9 \%)\end{array}$ & $\begin{array}{l}56(26.3 \%) \\
81(38.0 \%) \\
76(35.7 \%)\end{array}$ & 0.959 & 0.619 \\
\hline $\begin{array}{l}\text { Vegetables } \\
\text { Less than once/week } \\
\text { Once-thrid/week } \\
\text { More than third week }\end{array}$ & $\begin{array}{l}20(6.2 \%) \\
34(10.6 \%) \\
267(83.2 \%)\end{array}$ & $\begin{array}{l}8(3.7 \%) \\
23(10.7 \%) \\
183(85.5 \%)\end{array}$ & 1.61 & 0.447 \\
\hline $\begin{array}{l}\text { Friuts } \\
\text { Less than once/week } \\
\text { Once-thrid/week } \\
\text { More than third week }\end{array}$ & $\begin{array}{l}47(14.6 \%) \\
102(31.8 \%) \\
172(53.6 \%)\end{array}$ & $\begin{array}{l}\text { II }(5.1 \%) \\
44(20.6 \%) \\
159(74.3 \%)\end{array}$ & 25.517 & $<0.001$ \\
\hline $\begin{array}{l}\text { Sweet food } \\
\text { Less than once/week } \\
\text { Once-thrid/week } \\
\text { More than third week }\end{array}$ & $\begin{array}{l}150(46.7 \%) \\
100(31.2 \%) \\
71(22.1 \%)\end{array}$ & $\begin{array}{l}89(41.6 \%) \\
68(31.8 \%) \\
57(26.6 \%)\end{array}$ & 1.87 & 0.393 \\
\hline $\begin{array}{l}\text { Lard oil } \\
\text { Less than once/week } \\
\text { Once-thrid/week } \\
\text { More than third week }\end{array}$ & $\begin{array}{l}85(26.5 \%) \\
63(19.6 \%) \\
173(53.9 \%)\end{array}$ & $\begin{array}{l}77(36.0 \%) \\
58(27.1 \%) \\
79(36.9 \%)\end{array}$ & 14.86 & 0.001 \\
\hline $\begin{array}{l}\text { Spicy food } \\
\text { Less than once/week } \\
\text { Once-thrid/week } \\
\text { More than third week }\end{array}$ & $\begin{array}{l}101(31.3 \%) \\
103(31.9 \%) \\
119(36.8 \%)\end{array}$ & $\begin{array}{l}68(31.8 \%) \\
67(31.3 \%) \\
79(36.9 \%)\end{array}$ & 0.024 & 0.988 \\
\hline $\begin{array}{l}\text { Pork } \\
\text { Less than once/week } \\
\text { Once-thrid/week } \\
\text { More than third week }\end{array}$ & $\begin{array}{l}25(7.8 \%) \\
49(15.2 \%) \\
248(77.0 \%)\end{array}$ & $\begin{array}{l}19(8.9 \%) \\
46(21.5 \%) \\
149(69.6 \%)\end{array}$ & 4.002 & 0.135 \\
\hline
\end{tabular}

(Continued) 
Table 3 (Continued).

\begin{tabular}{|c|c|c|c|c|}
\hline \multirow[t]{2}{*}{ Characteristics } & \multicolumn{2}{|c|}{ Number of Patients* } & \multirow[t]{2}{*}{$\chi^{2}$} & \multirow[t]{2}{*}{$P$} \\
\hline & Male (325) & Female (214) & & \\
\hline \multicolumn{5}{|l|}{ Beef } \\
\hline Less than once/week & $153(47.7 \%)$ & 104 (48.6\%) & 0.383 & 0.826 \\
\hline Once-thrid/week & $112(34.9 \%)$ & 77 (36.0\%) & & \\
\hline More than third week & $56(17.4 \%)$ & 33 (I5.4\%) & & \\
\hline \multicolumn{5}{|l|}{ Family history } \\
\hline Yes & & 87 & & \\
\hline No & 209 (71.3\%) & $103(54.2 \%)$ & & \\
\hline \multicolumn{5}{|l|}{ Aggravate factors } \\
\hline \multicolumn{5}{|l|}{ Sun exposure } \\
\hline Yes & 93 (30.4\%) & 70 (33.0\%) & 0.401 & 0.527 \\
\hline No & $213(69.6 \%)$ & 142 (67.0\%) & & \\
\hline \multicolumn{5}{|l|}{ Menstrual cycle } \\
\hline Yes & $0(0.0 \%)$ & $|2|(56.8 \%)$ & 238.196 & $<0.001$ \\
\hline No & 325 (100.0\%) & 92 (43.2\%) & & \\
\hline \multicolumn{5}{|l|}{ Nervous } \\
\hline Yes & 132 (40.7\%) & I 27 (59.3\%) & 17.869 & $<0.001$ \\
\hline No & 192 (59.3\%) & 87 (40.7\%) & & \\
\hline \multicolumn{5}{|l|}{ Depressed } \\
\hline Yes & 70 (21.6\%) & 83 (38.8\%) & $|8.69|$ & $<0.001$ \\
\hline No & 254 (78.4\%) & $|3|(6 \mid .2 \%)$ & & \\
\hline \multicolumn{5}{|l|}{ Agrypnia } \\
\hline Yes & $93(28.7 \%)$ & 93 (43.5\%) & 12.403 & $<0.001$ \\
\hline No & 231 (71.3\%) & $12 \mid(56.5 \%)$ & & \\
\hline
\end{tabular}

Notes: $*$ There are some missing data. $P$ values $<0.05$ were marked in bold.

Table 4 Age and Gender Characteristics of Successfully Genotyped Cases and Controls

\begin{tabular}{|c|c|c|c|c|c|c|c|}
\hline & \multicolumn{2}{|c|}{ Gender (n) } & \multirow[t]{2}{*}{ Total } & \multirow[t]{2}{*}{$P+$} & \multirow[t]{2}{*}{ Age (Mean $\pm S D)$ of Years } & \multirow[t]{2}{*}{$\mathbf{t}^{*}$} & \multirow[t]{2}{*}{$\mathbf{P}^{*}$} \\
\hline & Male & Female & & & & & \\
\hline Control & 355 & 276 & 631 & 0.085 & $26.76 \pm 8.05$ & -5.37 & $<0.001$ \\
\hline Case & 348 & 221 & 569 & & $22.62 \pm 6.30$ & & \\
\hline
\end{tabular}

Notes: $+\chi^{2}$ test. *Student's $t$-test.

frequencies between the two groups (Table 7). We performed an overall haplotype test to analyze the global difference in haplotype frequencies between the case and control groups, which showed a significant difference (case vs control, $P=0.032$; male case vs male control, $P=0.011$ ). In particular, haplotype AGG was significantly associated with a lower risk of severe acne vulgaris in male patients $(\mathrm{OR}=0.697, P=0.009)$.
Inversely, haplotype AGA was significantly associated with a higher risk of severe acne vulgaris in male patients $(\mathrm{OR}=1.822, P=0.002)$, and haplotype AGA also affected risk in the whole patient group, but the $P$ value was only marginally significant $(\mathrm{OR}=1.350, P=$ 0.044 ), and this positive association disappeared after Bonferroni correction. For CYP19A1, we could not find any significant heterogeneity using either the overall 


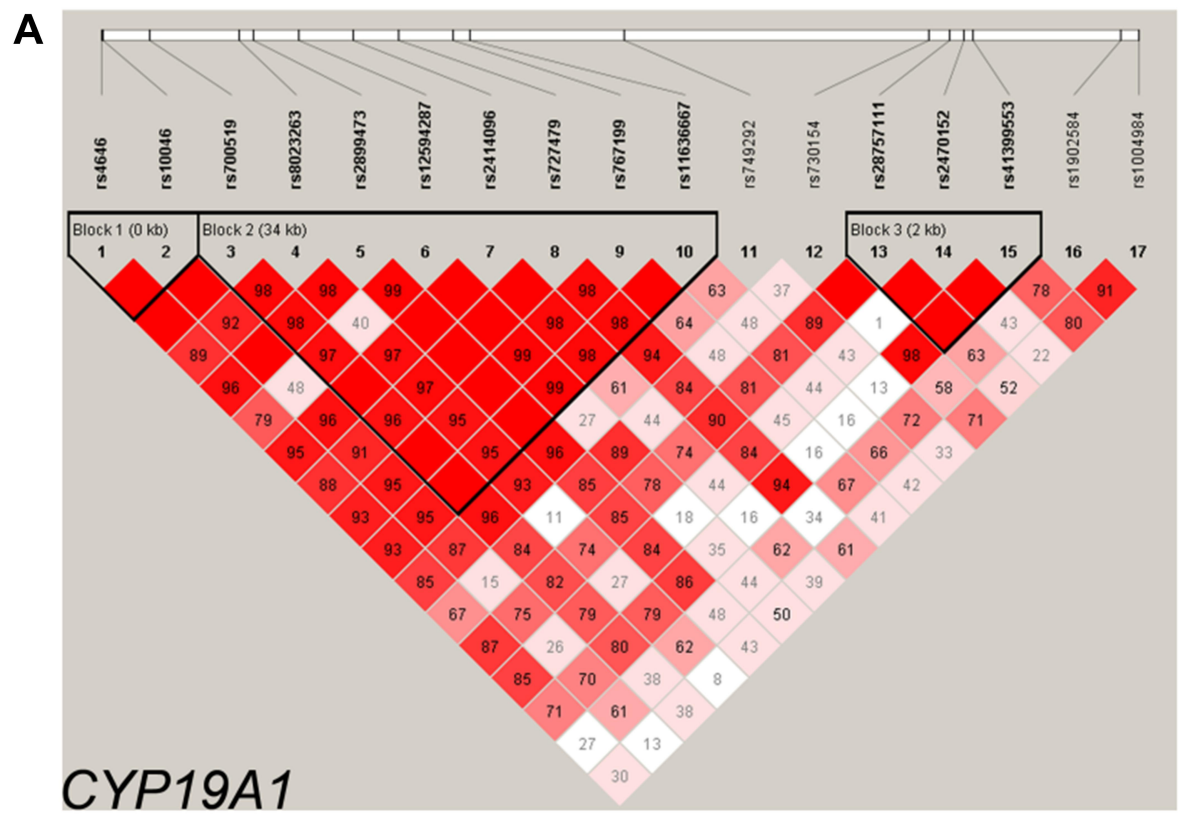

B

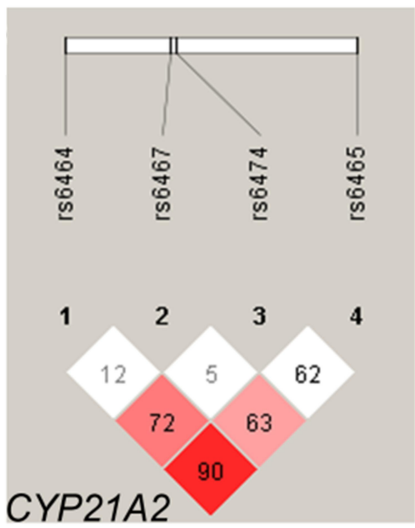

Figure I Linkage disequilibrium (LD) structures of the CYPI9AI gene (A) and the CYP2IA2 gene (B) in controls from Yunnan Province in China. The results are based on the data obtained in this study. Red squares represent high LD as measured by D', which gradually desaturate to white squares of low LD. Individual squares show the I00 $\times$ D' value for each SNP pair.

haplotype test or single haplotype test for all subjects or after stratification by gender $(P>0.05)$.

\section{Functional Implications of the SNP rs6474 (p. Arg 102Lys) from Structure}

Bovine and human sequences share $79 \%$ sequence identity. The overall structure of the human CYP21A2 exhibited the typical P450 fold consisting of $\alpha$-helical and $\beta$ sheet domains. The structure consists of two substrate binding sites ( $\mathrm{S} 1$ and $\mathrm{S} 2$ ) and one substrate access channel (Figure 2A). Residues K98, L99, V100, S101, R102, N103, Y104, R223 and D234 lie within $5 \AA$ of the substrate-binding site (S1) (Figure 2B).

\section{Discussion}

Both genetic factors and androgens play an important role in the predisposition to acne vulgaris, ${ }^{3,5}$ which is one of the clinical features of hyperandrogenemia. Furthermore, acne occurs earlier and is more severe in those with a family history of acne. ${ }^{4}$ To date, however, there are few reports on the association between polymorphisms or mutations of genes and acne.

Most studies have been population-based case and control studies, based on a small number sample, of certain steroid hormone-related genes, $A R \mathrm{~s},{ }^{9}$ human cytochrome P450 $1 A 1$ genes $(C Y P 1 A 1),{ }^{8}$ steroid 21-hydroxylase $\left(\right.$ CYP21A2) ${ }^{10}$ steroid 17-hydroxylase (CYP17), ${ }^{5}$ and innate immunity genes, such as toll-like receptors type 2 (TLR2), ${ }^{3}$ toll-like receptors type 4 (TLR4), ${ }^{27}$ tumor necrosis factoralpha $(T N F-\alpha),{ }^{28}$ tumor necrosis factor receptor type 2 (TNFR2) 2, and interleukin-10 (IL-10). ${ }^{28}$ Androgens/ARs signaling pathway is essential for the formation of acne. Testosterone can convert to $5 \alpha$-dihydrotestosterone (DHT) by the $5 \alpha$-reductase. Three kinds of $5 \alpha$-reductase have been identified with different patterns of expression. Sebocytes and keratinocytes are the cells mainly expressing the type I $5 \alpha$-reductase. Type II $5 \alpha$-reductase is mainly observed in seminal vesicles, prostate, and epididymis. The third type of $5 \alpha$-reductase is mostly found in prostate cancer. Infections lead to generation of acne in the hair follicle, which induces activation and migration of neutrophils and macrophages to the follicles. These cells are activated by $A R$-mediated signals and secret pro-inflammatory factors including IL-6, IL12 and TNF- $\alpha$, thereby aggravating the inflammatory responses and infection. ${ }^{29,30}$ In this study, we successfully genotyped 21 gene variants of the CYP19A1 and CYP21A2 genes. We found that two tag SNPs (rs6474 and rs6465) in the CYP21A2 gene were significantly associated with Pillsbury III-IV severe acne vulgaris, particularly among male patients with severe acne vulgaris. Genotype AA of rs6474 (p.Arg102Lys) of the CYP21A2 gene showed a high risk for severe acne vulgaris and male severe acne vulgaris, while genotype TT of rs6465 conferred a weak protective effect against severe acne vulgaris and male severe acne 


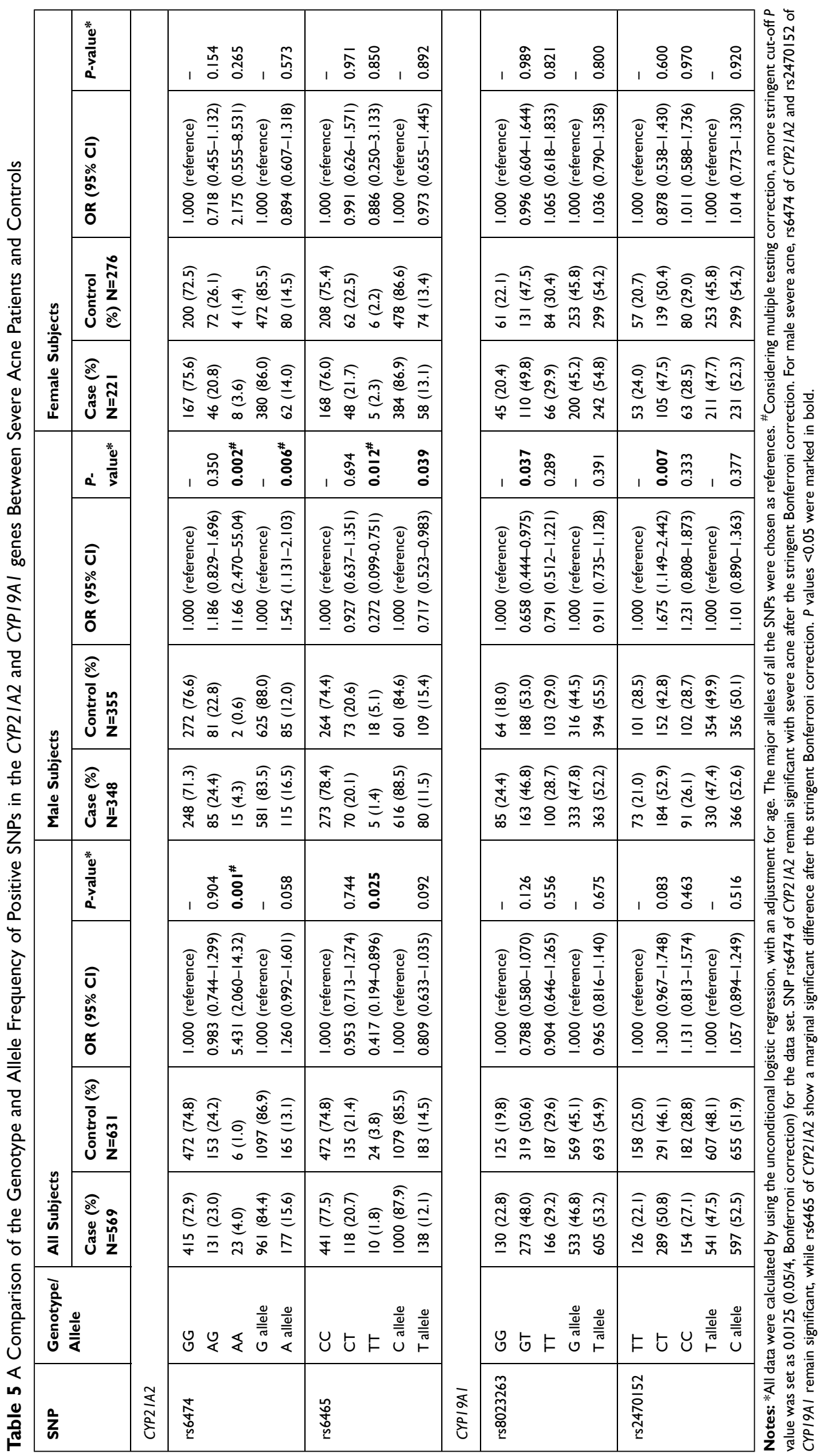




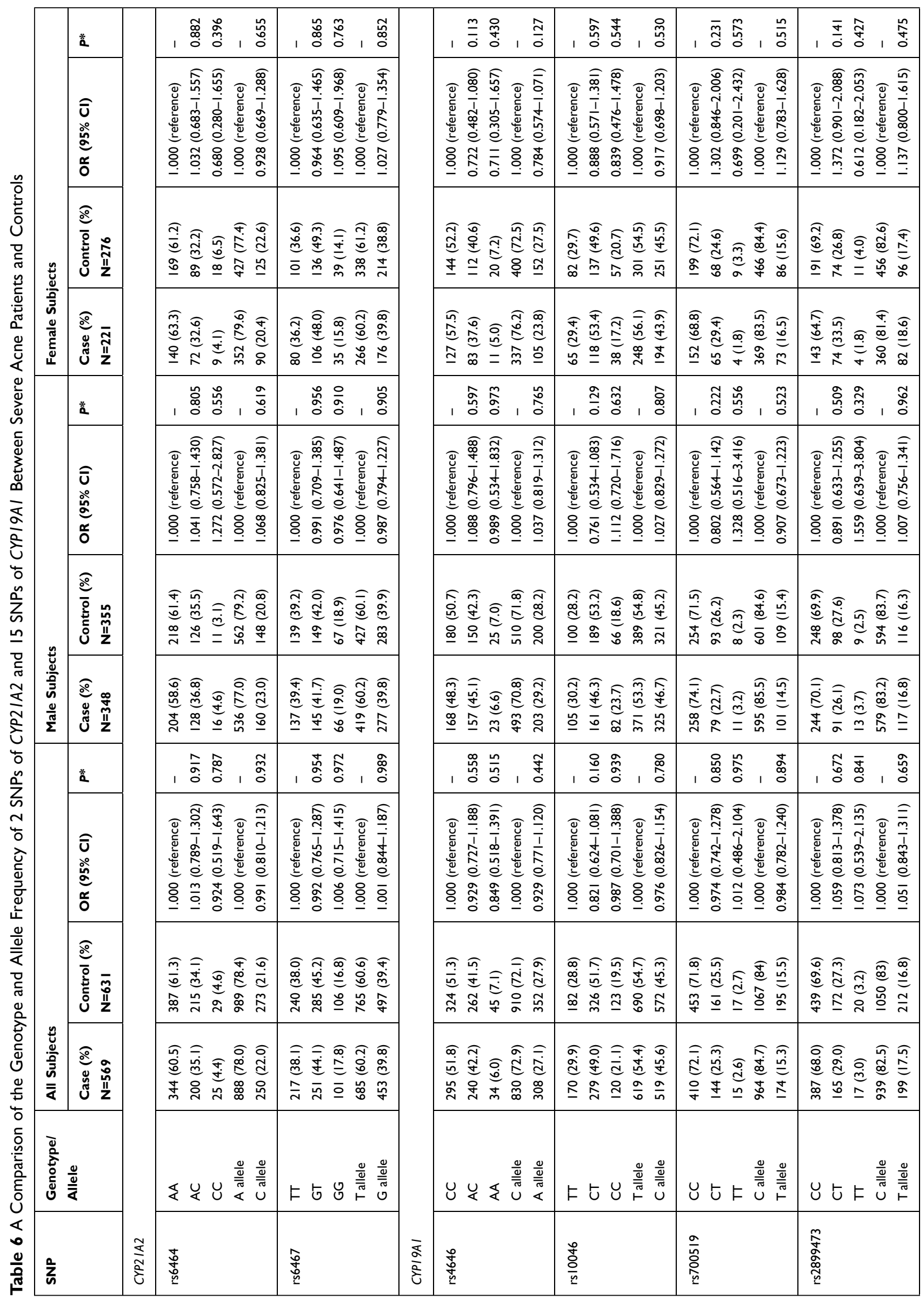




\begin{tabular}{|c|c|c|c|c|c|c|}
\hline , 胥 & 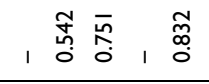 & 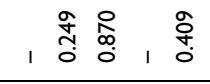 & 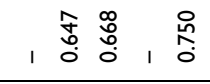 & 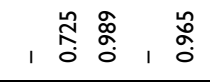 & , & 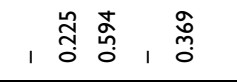 \\
\hline 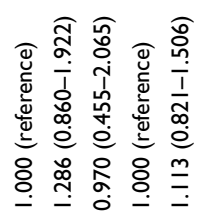 & 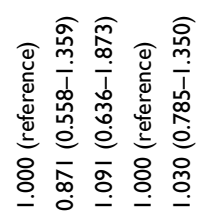 & 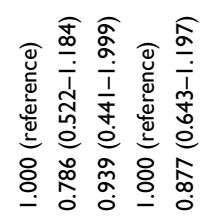 & 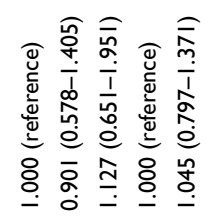 & 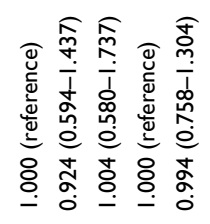 & 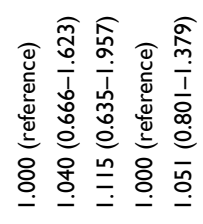 & 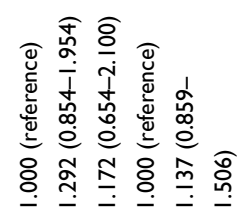 \\
\hline 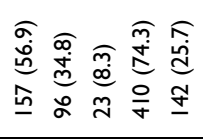 & 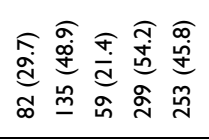 & 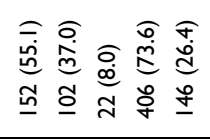 & 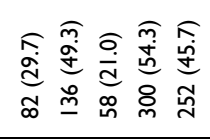 & 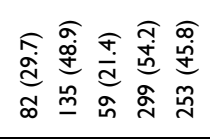 & 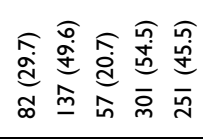 & 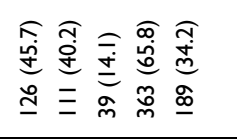 \\
\hline 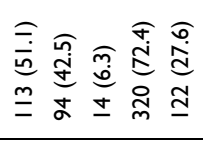 & 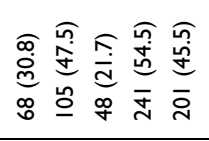 & 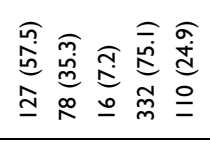 & 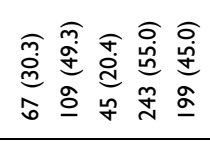 & 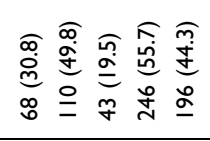 & 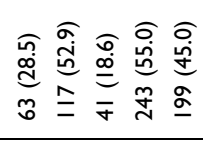 & 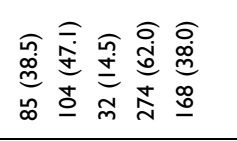 \\
\hline , 总兑 & 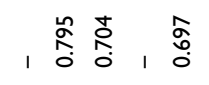 & 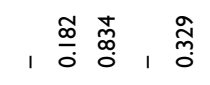 & 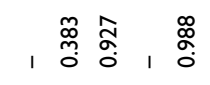 & , & , $\underset{0}{\stackrel{0}{0} \frac{n}{0}}, \frac{\bar{n}}{0}$ & 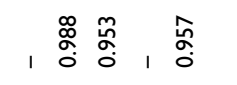 \\
\hline 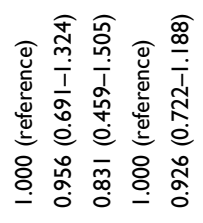 & 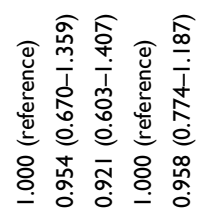 & 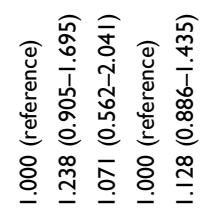 & 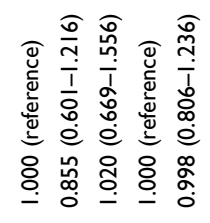 & 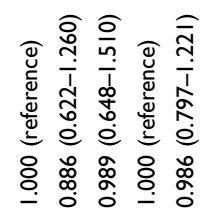 & 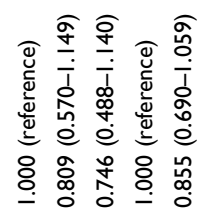 & 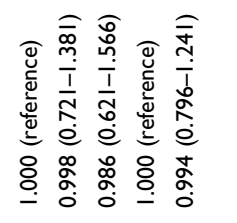 \\
\hline 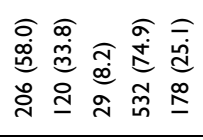 & 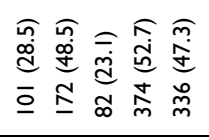 & 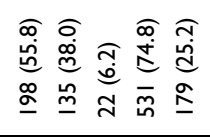 & 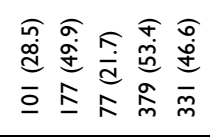 & 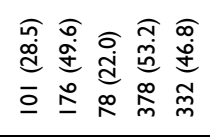 & 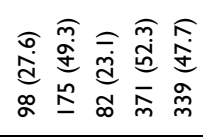 & 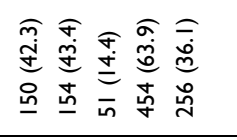 \\
\hline 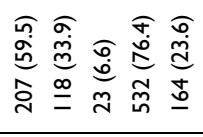 & 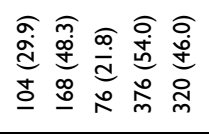 & 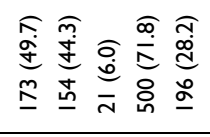 & 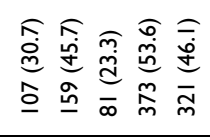 & 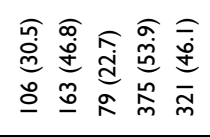 & 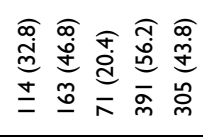 & 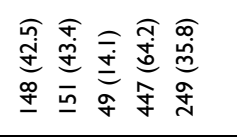 \\
\hline 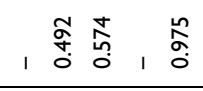 & 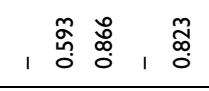 & 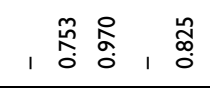 & 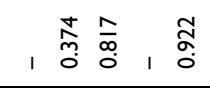 & 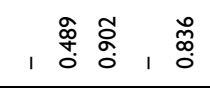 & 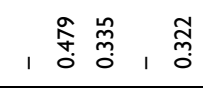 & , 总 $\begin{array}{c}\text { ô } \\
0\end{array}$ \\
\hline 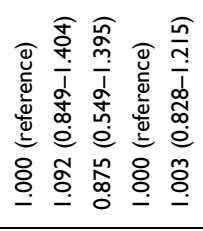 & 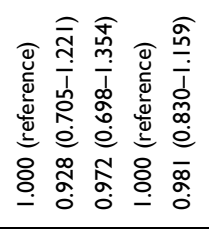 & 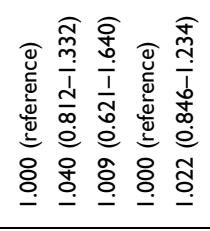 & 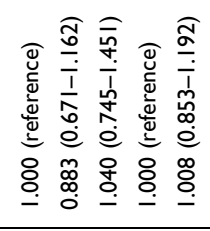 & 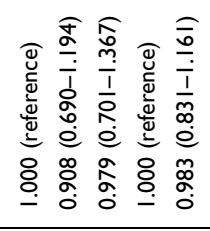 & 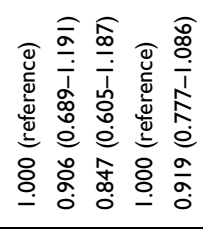 & 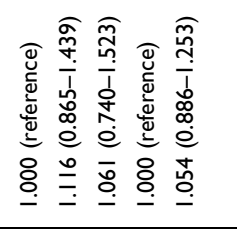 \\
\hline 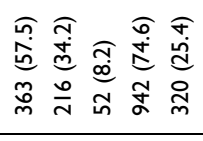 & 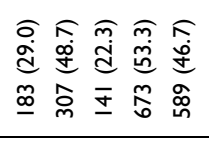 & 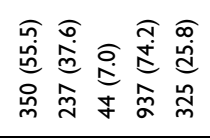 & 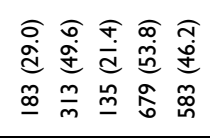 & 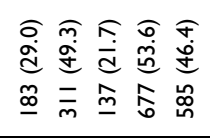 & 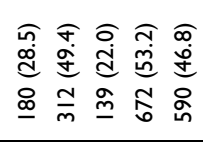 & 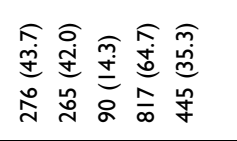 \\
\hline 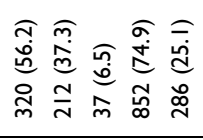 & 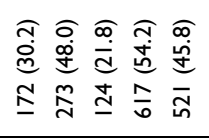 & 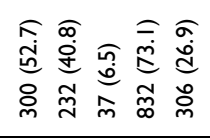 & 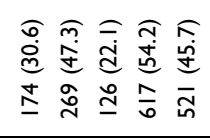 & 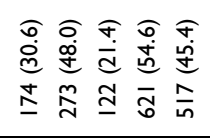 & 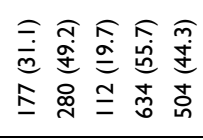 & 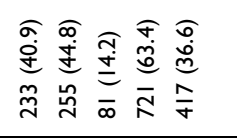 \\
\hline 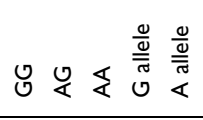 & 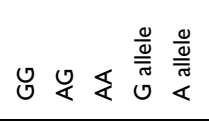 & 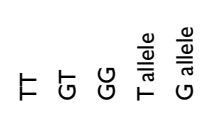 & U U & 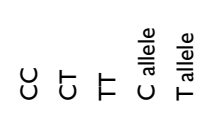 & OU & 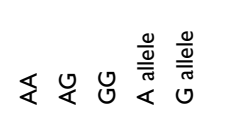 \\
\hline 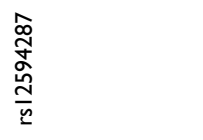 & 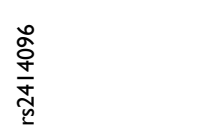 & 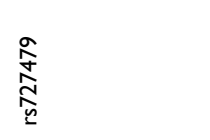 & $\frac{\sigma}{\frac{\sigma}{a}}$ & $\begin{array}{l}\hat{o} \\
\stackrel{\circ}{0} \\
\underline{\underline{0}} \\
\overline{\underline{n}}\end{array}$ & 商 & 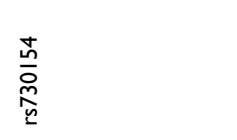 \\
\hline
\end{tabular}




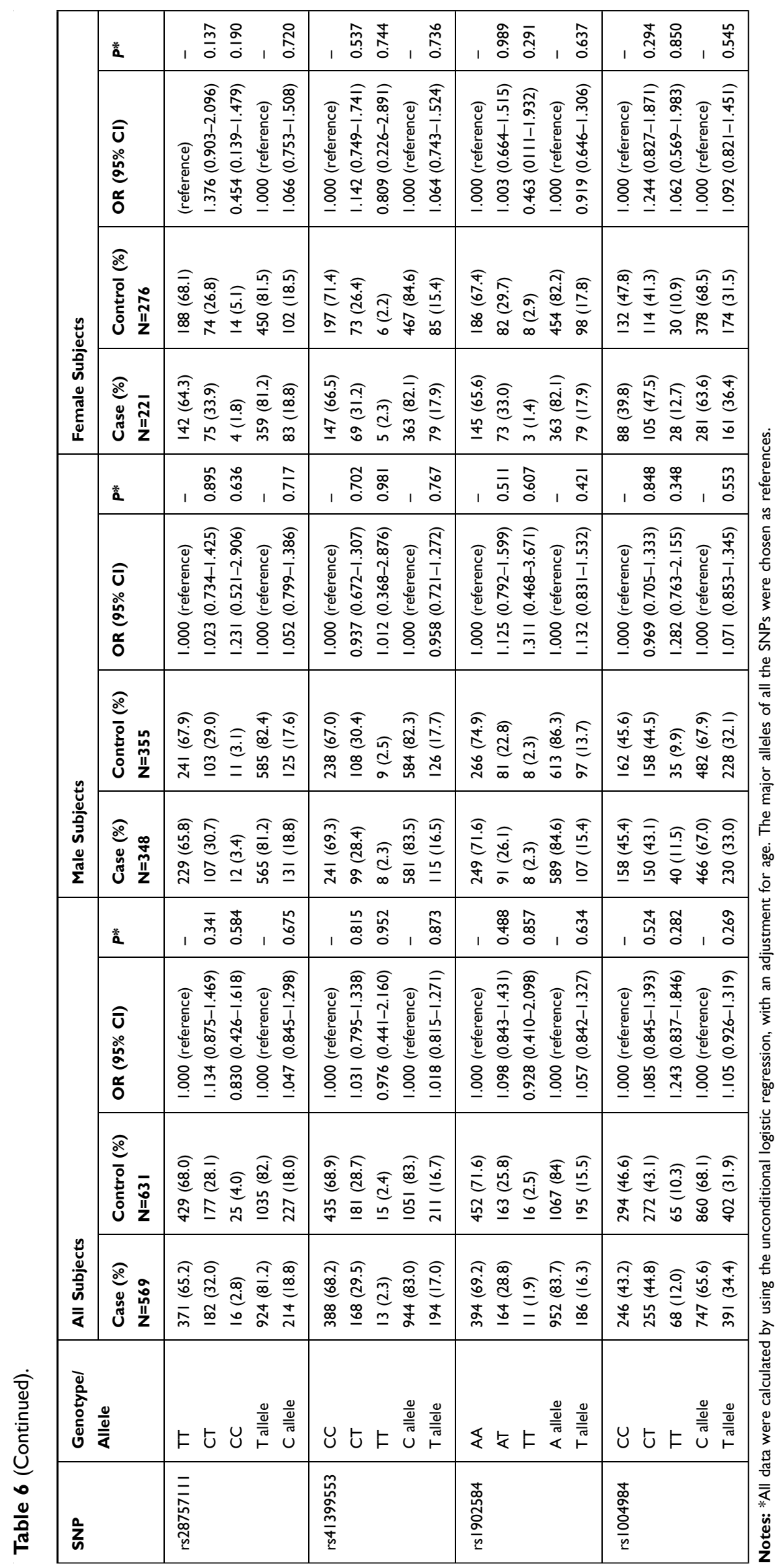




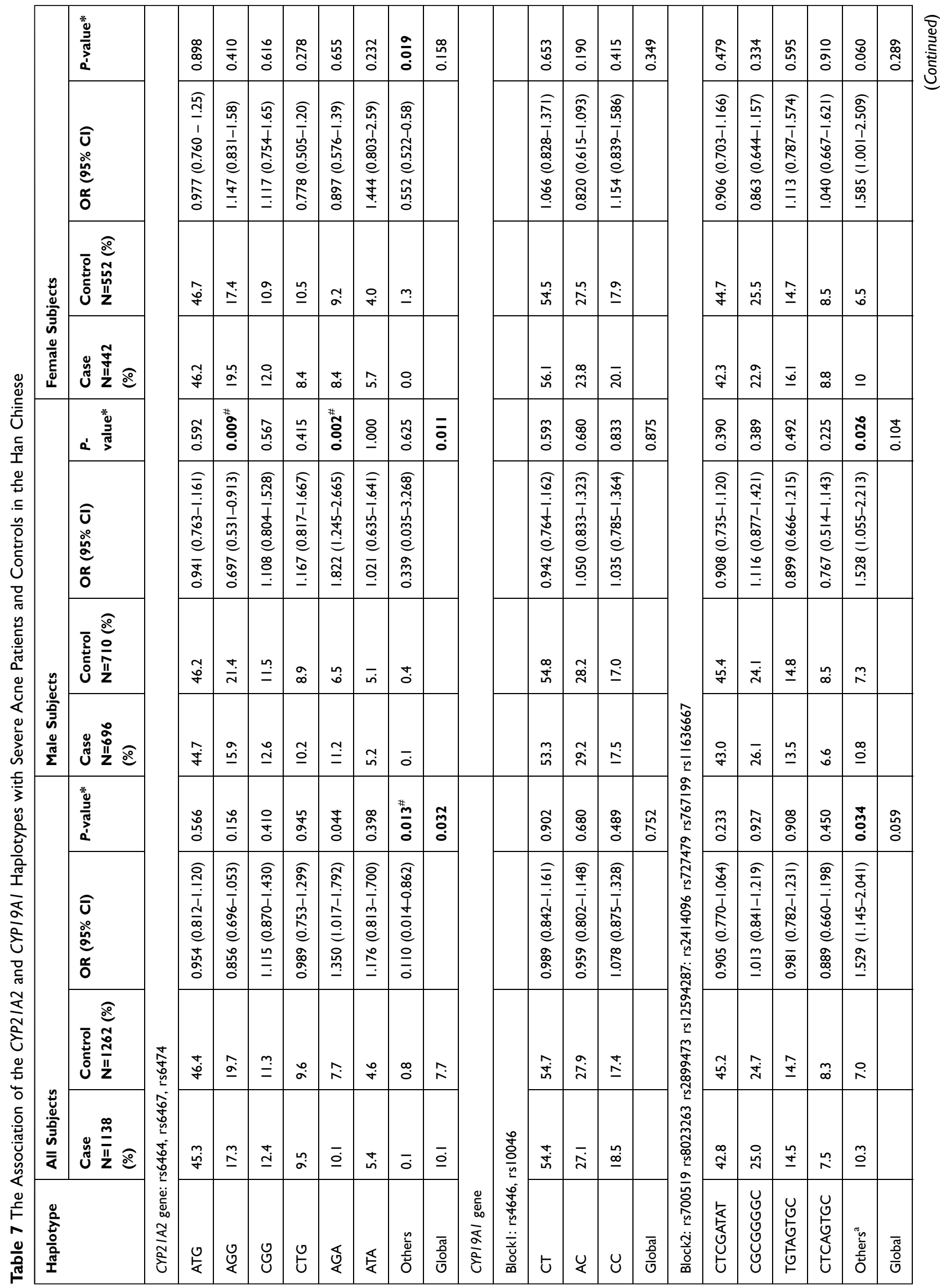




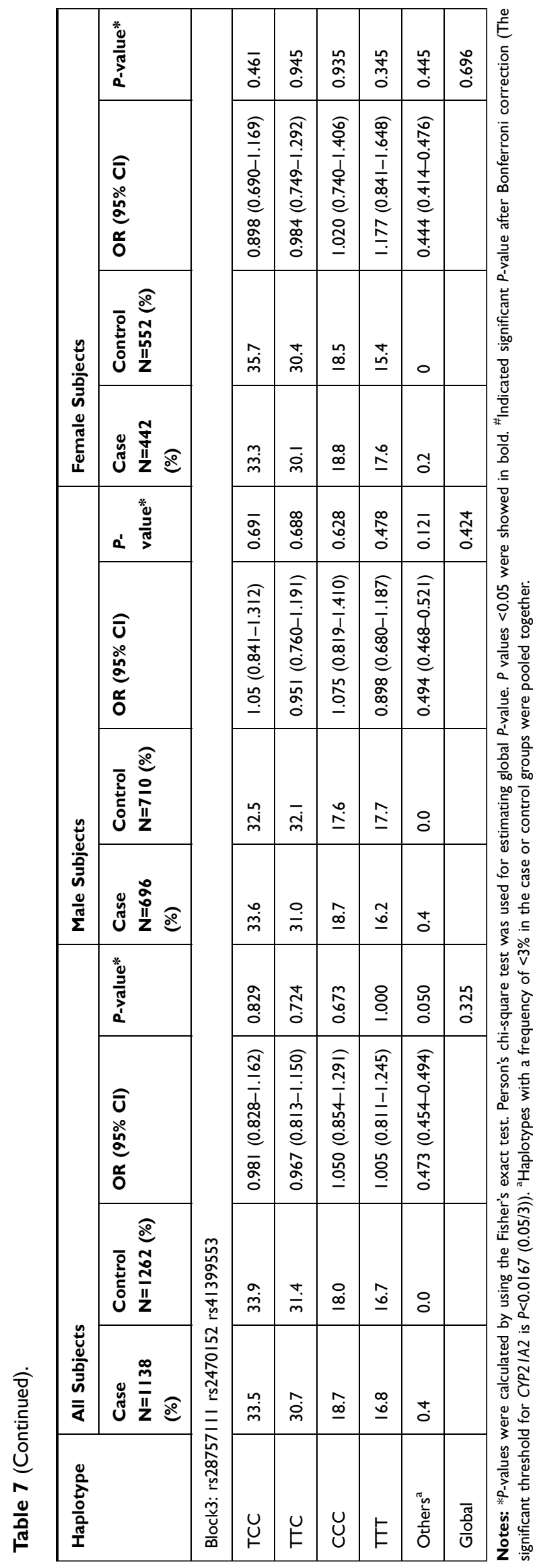

vulgaris. The minor allele A of rs6474 (p.Arg102Lys) conferred a strong predisposition to male severe acne vulgaris and minor allele $\mathrm{T}$ of rs6465 showed a weak protective effect on male severe acne vulgaris (Table 5).

Unfortunately, we failed to find any association between severe acne vulgaris and four well-reported SNPs [rs4646 and rs10046 (in the 3'-UTR), rs700519 (Arg264Cys), rs2414096] of other androgen-related diseases. However, we found genotypes of two tag SNPs (rs8023263 and rs2470152) in the noncoding region of the CYP19A1 gene were associated with male patients with severe acne vulgaris. The Genotype GT of rs8023263 conferred a weak protective effect on male severe acne vulgaris patients, whereas heterozygote CT of rs 2470152 showed a significant risk for male severe acne vulgaris patients. We found that the most frequent haplotype AGG of the CYP21A2 gene tended to provide a protective effect for male patients with severe acne vulgaris, whereas haplotype AGA conferred a risk-effect towards male patients with severe acne vulgaris. This disparity suggests that the gene variant rs6474 (p.Arg102Lys) may be a causative SNP in severe acne vulgaris, especially for among males. However, for CYP19A1, we could not find any significant heterogeneity.

A growing number of studies of gene variants of CYP21A2 focus on an autosomal recessive inherited disorder of steroid metabolism, known as congenital adrenal hyperplasia (CAH), which has been classified into a classical (C-CAH) and a nonclassical (NC-CAH) form. ${ }^{31}$ Further studies using molecular screening techniques found that the mutation of CYP21A2 was more common in unselected acne patients than in controls, further supporting the possibility that the CYP21A2 gene may contribute to the variability of the clinical phenotype in hyperandrogenic states, including acne. ${ }^{10,32}$

In this study, we found that the two novel SNPs of CYP21A2, rs6474 (p.Arg102Lys) and rs6465, may confer a susceptibility to severe acne vulgaris, particularly for males. Rs6474 (p.Arg102Lys), located on the extron 3 of CYP21A2, may reduce the activity of 21-hydroxylase, which can result in adrenal androgen excess and contribute to the clinical manifestations of male severe acne vulgaris. Bovine shares $79 \%$ sequence identity with humans. The typical P450 fold, which was composed of $\alpha$-helical and $\beta$-sheet domains, was showed in the structure of human CYP21A2. The structure consists of two substrate binding sites (S1 and S2) and one substrate access channel (Figure 2A). These local structures are critical for the function of $C Y P 21 A 2$. Mutations at these local structures may affect binding and converting of the substrate $17-\mathrm{OHP}$, thus causing multiple related diseases, 


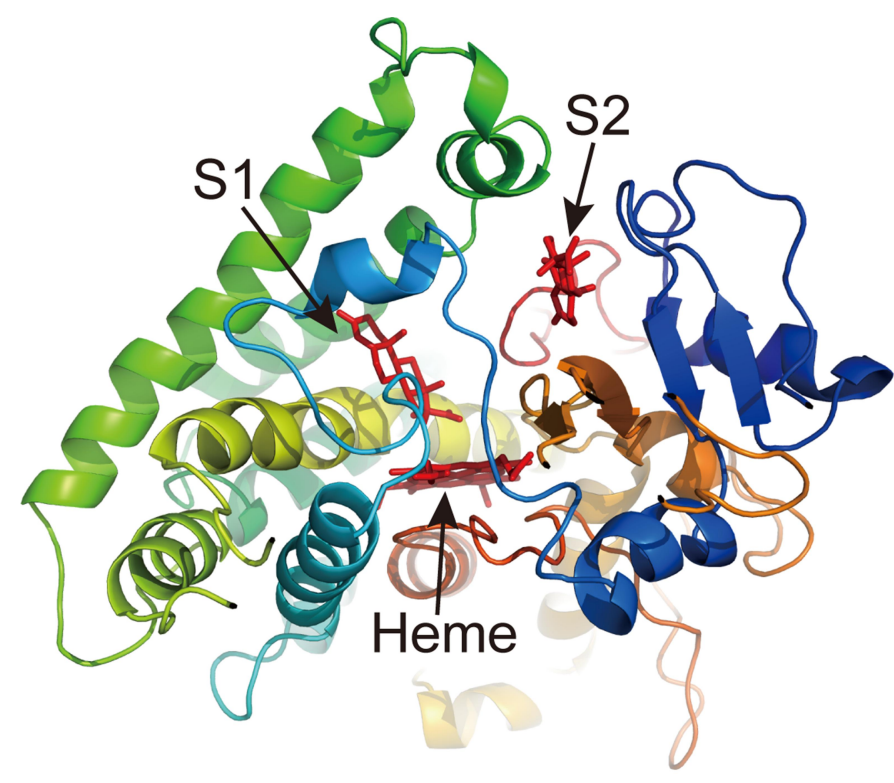

A

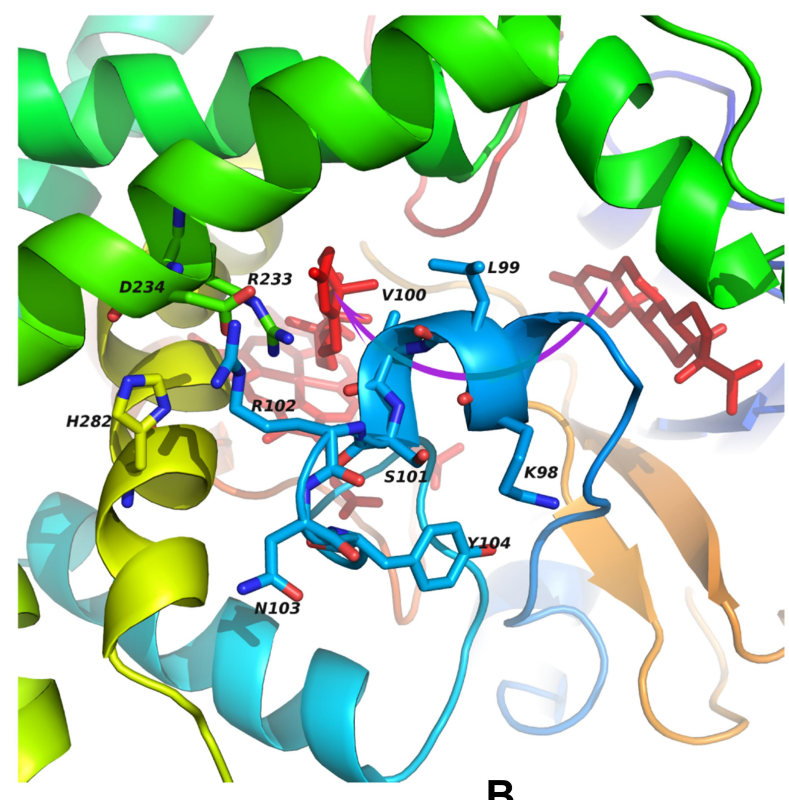

B

Figure 2 The structure of human CYP2IA2 complexed with 17-OHP. (A) The overview of the binding mode of I7-OHP to CYP2IA2. Secondary structural elements are colored from blue (N-terminus) to red (C-terminus). The ligand I7-OHP (SI and S2) and heme are colored red. (B) A close-up view of the binding mode of I7-OHP to the binding cavity $(\mathrm{SI})$ of CYP2IA2. The residues involved in binding and accessing of substrate are labeled and shown as sticks. The purple arrow represents the substrate access channel.

including severe acne vulgaris. Residues K98, L99, V100, S101, R102, N103, Y104, R223, and D234 lie within $5 \AA$ of substrate-binding site (S1) (Figure 2B). In our study, the SNP rs6474 (p.Arg102Lys) was identified in severe acne vulgaris patients. The structure analysis above suggests a strong association between this SNP and severe acne vulgaris.

However, the SNP of rs6465 in the intron region of the CYP21A2 gene has a protective effect on male severe acne vulgaris, and variations in the introns may affect regulatory sequences in close proximity or in combination with some other functional polymorphisms, resulting in a change in the protein sequence of 21-hydroxylase, which may cause a dominant-negative effect of 21-hydroxylase activity in acne patients. The analysis of haplotypes corroborated our single-marker results by showing that the haplotypes were significant in male patients with severe acne vulgaris, thus confirming the importance of the CYP21A2 gene in severe acne vulgaris in males. Accordingly, we speculate that risk alleles and genotypes of rs6467 and risk haplotypes of the CYP21A2 gene might have a greater influence on 21-hydroxylase expression. Taking these findings into account, our data suggest that the CYP21A2 gene might be actively involved in male severe acne vulgaris. Further independent replication analysis and functional assays should be carried out to further clarify the exact role of the CYP21A2 gene in this disease.
The polymorphisms of CYP19A1 have been evaluated in relation to androgen-related diseases (prostate cancer, PCOS) and estrogen-related diseases (breast cancer, endometrial cancer, endometriosis) with mixed results. The polymorphisms of the CYP19A1 gene encoding aromatase have been correlated with plasma testosterone levels, so CYP19A1 may therefore act as a genetic modifier of the hyperandrogenic phenotype of severe acne vulgaris. Despite these results and our strong suspicions of their potential role in acne, we found no significant association with severe acne vulgaris of the reported SNPs, rs4646 and rs10046 (in the 3'-UTR), rs700519 (Arg264Cys), and rs2414096, which had been implicated in hyperandrogenism diseases.

However, we identified a heterozygous genotype of two tag SNPs (the GT of rs8023263 and CT of rs2470152) of this gene as being significantly associated with severe acne among Han Chinese males. SNP rs8023263, located in an intron region, was similarly associated, and it could be linked to some other functional polymorphisms, or it might influence the level of gene expression related to aromatase activity. Published data that suggested the association of those polymorphisms in the intron region or a synonymous mutation of CYP19A1 associated with aromatase activity is in line with our hypothesis that SNP rs 8023263 might be related with aromatase activity involved in the pathophysiology of acne formation. Therefore, the genotypes GT of rs8023263 and CT of 
rs2470152 may have a potential effect on the activity of aromatase and be involved in the development of severe acne vulgaris in males.

The findings of significant association between these genes and male patients with severe acne vulgaris, though interesting, do leave some questions to be resolved, foremost being why significant associations were only observed among severe acne vulgaris patients. This observation, along with our previous findings that androgen-related genes CYP17 -34 C/T also contribute to severe acne pathogenesis, largely rests on the position that the genetic elements are more important in severe acne and not in mild acne, the latter appearing to be more related to environmental factors and individual lifestyle. Acne is also more severe in those with a positive family history, ${ }^{4}$ suggesting that hereditary factors are potentially responsible for severe acne. The second major question to consider is what accounts for the gender-based differences we observed. In females, the polymorphisms with acne are not as clear and obvious as those in males, since the genetic, metabolic and hormonal factors differ between the two of them. Moreover, estrogen and estrogen-related genes, as well as the homeostatic balance between androgens and estrogens, may play an important role in female acne. The clinical data in the present study showed that females are more prone to be affected by the emotions of stress and depression and may also experience poor quality of sleep and irregular menstrual cycles. In light of these differences, it may potentially be that environmental factors play a more significant role in female acne and, as such, should be more fully explored so that the differences in male and female experience of the environmental conditions related to acne susceptibility can be understood. Clearly, the multifactorial and polygenic nature of acne necessitate further study to investigate the potential mechanism between different phenotypes, including severity and gender discrepancies, confounding factors, and other genetic elements.

There are some limitations to this present study. First, although we can hypothesize as to the manner in which these genes are connected with severe acne and similar diseases, our study is merely suggestive of these underlying mechanisms, and further studies that can more fully map out the actions of these genes are needed. Second, we only analyzed the association of CYP21A2 and CYP19A1 with acne, without long-term studies of functional assays. Moreover, while numerous studies point out that androgens do play a role in the pathogenesis of acne vulgaris, the results were somewhat discordant. The circulating levels of these hormones were often within the normal range, and we did not estimate hormone parameters between the acne patients and healthy controls. Nevertheless, the data concerning hormone parameters may be useful in future observations of the activity of 21-hydroxylase (serum 17-OHP) and aromatase (E2/T ratio). This will greatly aid in mapping out the connections of the CYP21A2 and CYP19A1 genes, as well as their coding enzymes, with severe acne vulgaris and, thus, better explain our results. In addition, we only analyzed four tag SNPs for the CYP21A2 gene, which greatly limits our ability to cover the entire gene and may have yielded a less complete picture of this gene's potential associations.

In conclusion, we found two different alleles and genotypes of rs6474 and rs6465, as well as haplotypes of the CYP21A2 gene, positively associated with Pillsbury III-IV severe acne vulgaris in males, and the genotypes GT of rs8023263 as well as CT of rs2470152 of the CYP19A1 gene were also associated with Pillsbury III-IV severe acne vulgaris. These results suggest that genetic variations of androgen-related genes can cause alterations either in the fine regulation of these genes or in the function of the resulting proteins, which can result in imbalances in the levels of androgen and estrogen, potentially conferring a subsequent susceptibility to androgen-related diseases.

\section{Acknowledgments}

We thank all the participants in this study and Mr. Ya-ping Zhang's lab for providing experimental facilities.

\section{Funding}

This study was supported by the National Natural Science Foundation of China (81960563, 81760559), Yunnan Science and Technology Leading Talents Project (2017HA010), Huangshi Science and Technology Bureau and Health Bureau joint fund (2016).

\section{Disclosure}

The authors declare that they have no competing interests.

\section{References}

1. Tan JK, Bhate K. A global perspective on the epidemiology of acne. Br J Dermatol. 2015;172 (Suppl 1):3-12. doi:10.1111/bjd.13462

2. Tan JK. Psychosocial impact of acne vulgaris: evaluating the evidence. Skin Therapy Lett. 2004;9 (7):1-3, 9.

3. Tian LM, Xie H-F, Yang T, et al. Association study of tumor necrosis factor receptor type $2 \mathrm{M} 196 \mathrm{R}$ and toll-like receptor 2 Arg753Gln polymorphisms with acne vulgaris in a Chinese Han ethnic group. Dermatology. 2010;221 (3):276-284. doi:10.1159/000319851

4. Bhate K, Williams HC. Epidemiology of acne vulgaris. Br J Dermatol. 2013;168 (3):474-485. doi:10.1111/bjd.12149

5. He L, Yang Z, Yu H, et al. The relationship between CYP17-34T/C polymorphism and acne in Chinese subjects revealed by sequencing. Dermatology. 2006;212 (4):338-342. doi:10.1159/000092284 
6. Keshari S, Kumar M, Balasubramaniam A, Chang TW, Tong Y, Huang CM. Prospects of acne vaccines targeting secreted virulence factors of Cutibacterium acnes. Expert Rev Vaccines. 2019;18 (5):433-437. doi:10.1080/14760584.2019.1593830

7. Kuiri-Hänninen T, Haanpää M, Turpeinen U, et al. Transient postnatal secretion of androgen hormones is associated with acne and sebaceous gland hypertrophy in early infancy. $J$ Clin Endocrinol Metab. 2013;98 (1):199-206. doi:10.1210/jc.2012-2680

8. Paraskevaidis A, Drakoulis N, Roots I, et al. Polymorphisms in the human cytochrome P-450 1A1 Gene (CYP1A1) as a factor for developing acne. Dermatology. 1998;196 (1):171-175. doi:10.1159/000017855

9. Pang Y, He CD, Liu Y, et al. Combination of short CAG and GGN repeats in the androgen receptor gene is associated with acne risk in North East China. J Eur Acad Dermatol Venereol. 2008;22 (12):1445-1451. doi:10.1111/j.1468-3083.2008.02891.x

10. Ostlere LS, Rumsby G, Holownia P, et al. Carrier status for steroid 21-hydroxylase deficiency is only one factor in the variable phenotype of acne. Clin Endocrinol. 1998;48 (2):209-215. doi:10.1046/ j.1365-2265.1998.3811205.x

11. Travis RC, Schumacher F, Hirschhorn JN, et al. CYP19A1 genetic variation in relation to prostate cancer risk and circulating sex hormone concentrations in men from the breast and prostate cancer cohort consortium. Cancer Epidemiol Biomarkers Prev. 2009;18 (10):2734-2744. doi:10.1158/1055-9965.EPI-09-0496

12. Lazaros L, Xita N, Hatzi E, et al. CYP19 gene variants affect the assisted reproduction outcome of women with polycystic ovary syndrome. Gynecol Endocrinol. 2013;29 (5):478-482. doi:10.3109/ 09513590.2013 .774359

13. Wang H, Li Q, Wang T, et al. A common polymorphism in the human aromatase gene alters the risk for polycystic ovary syndrome and modifies aromatase activity in vitro. Mol Hum Reprod. 2011;17 (6):386-391. doi:10.1093/molehr/gar007

14. Onsory K, Sobti RC, Al-Badran AI, et al. Hormone receptor-related gene polymorphisms and prostate cancer risk in North Indian population. Mol Cell Biochem. 2008;314 (1-2):25-35. doi:10.1007/s11010008-9761-1

15. Yip L, Zaloumis S, Irwin D, et al. Gene-wide association study between the aromatase gene (CYP19A1) and female pattern hair loss. Br J Dermatol. 2009;161 (2):289-294. doi:10.1111/j.13652133.2009.09186.x

16. Ramalhinho AC, Fonseca-Moutinho JA, Breitenfeld Granadeiro LA. Positive association of polymorphisms in estrogen biosynthesis gene, CYP19A1, and metabolism, GST, in breast cancer susceptibility. DNA Cell Biol. 2012;31 (6):1100-1106. doi:10.1089/dna.2011.1538

17. Khvostova EP, Pustylnyak VO, Gulyaeva LF. Genetic polymorphism of estrogen metabolizing enzymes in Siberian women with breas cancer. Genet Test Mol Biomarkers. 2012;16 (3):167-173. doi:10.1089/gtmb.2011.0131

18. Lundin E, Wirgin I, Lukanova A, et al. Selected polymorphisms in sex hormone-related genes, circulating sex hormones and risk of endometrial cancer. Cancer Epidemiol. 2012;36 (5):445-452. doi:10.1016/j.canep.2012.04.006
19. Wang HS, Wu HM, Cheng BH, et al. Functional analyses of endometriosis-related polymorphisms in the estrogen synthesis and metabolism-related genes. PLoS One. 2012;7 (11):e47374. doi:10.1371/ journal.pone.0047374

20. Trabert B, Schwartz SM, Peters U, et al. Genetic variation in the sex hormone metabolic pathway and endometriosis risk: an evaluation of candidate genes. Fertil Steril. 2011;96 (6):1401-1406 e3. doi:10.1016/j.fertnstert.2011.09.004

21. Xita N, Chatzikyriakidou A, Stavrou I, et al. The (TTTA) n polymorphism of aromatase (CYP19) gene is associated with age at menarche. Hum Reprod. 2010;25 (12):3129-3133. doi:10.1093/humrep/deq276

22. Guo Y, Xiong D-H, Yang T-L, et al. Polymorphisms of estrogenbiosynthesis genes CYP17 and CYP19 may influence age at menarche: a genetic association study in Caucasian females. Hum Mol Genet. 2006;15 (16):2401-2408. doi:10.1093/hmg/ddl155

23. Witkowski JA, Parish LC. The assessment of acne: an evaluation of grading and lesion counting in the measurement of acne. Clin Dermatol. 2004;22 (5):394-397. doi:10.1016/j.clindermatol.2004.03.008

24. Tao SQ, Xia R-S, Li F, et al. Efficacy of 3.6\% topical ALA-PDT for the treatment of severe acne vulgaris. Eur Rev Med Pharmacol Sci. 2016;20 (2):225-231.

25. Barrett JC, Fry B, Maller J, et al. Haploview: analysis and visualization of LD and haplotype maps. Bioinformatics. 2005;21 (2):263265. doi:10.1093/bioinformatics/bth457

26. Gabriel SB, Schaffner SF, Nguyen H, et al. The structure of haplotype blocks in the human genome. Science. 2002;296 (5576):22252229. doi:10.1126/science. 1069424

27. Grech I, Giatrakou S, Damoraki G, et al. Single nucleotide polymorphisms of toll-like receptor-4 protect against acne conglobata. $J$ Eur Acad Dermatol Venereol. 2012;26 (12):1538-1543. doi:10.1111/ j.1468-3083.2011.04338.x

28. Al-Shobaili HA, Salem TA, Alzolibani AA, et al. Tumor necrosis factor- $\alpha-308 \mathrm{G} / \mathrm{A}$ and interleukin 10-1082 A/G gene polymorphisms in patients with acne vulgaris. J Dermatol Sci. 2012;68 (1):52-55. doi:10.1016/j.jdermsci.2012.07.001

29. Karrer-Voegeli S, Rey F, Reymond MJ, Meuwly JY, Gaillard RC, Gomez F. Androgen dependence of hirsutism, acne, and alopecia in women: retrospective analysis of 228 patients investigated for hyperandrogenism. Medicine. 2009;88 (1):32-45. doi:10.1097/ md.0b013e3181946a2c

30. Lai JJ, Chang P, Lai KP, Chen L, Chang C. The role of androgen and androgen receptor in skin-related disorders. Arch Dermatol Res. 2012;304 (7):499-510.

31. New MI. An update of congenital adrenal hyperplasia. Ann N Y Acad Sci. 2004;1038:14-43. doi:10.1196/annals.1315.009

32. Caputo V, Fiorella S, Curiale S, et al. Refractory acne and 21-hydroxylase deficiency in a selected group of female patients. Dermatology. 2010;220 (2):121-127. doi:10.1159/000277608
Clinical, Cosmetic and Investigational Dermatology is an international, peer-reviewed, open access, online journal that focuses on the latest clinical and experimental research in all aspects of skin disease and cosmetic interventions. This journal is indexed on CAS
The manuscript management system is completely online and includes a very quick and fair peer-review system, which is all easy to use. Visit http://www.dovepress.com/testimonials.php to read real quotes from published authors. 